\title{
Laporan Kasus: Kandidiasis Akut Eritematous pada Penderita Diabetes Melitus
}

\section{(Case Report: Candidiasis Acute Erythematous of Diabetes Mellitus Patients)}

\section{Aris Aji Kurniawan', Tirta Wardana ${ }^{2}$, Arif Rachman Darmawan ${ }^{3}$}

1 Bagian IImu Penyakit Mulut, Jurusan Kedokteran Gigi, Fakultas Kedokteran, Universitas Jenderal Soedirman, Purwokerto, Indonesia.

2 Bagian Biologi Molekuler, Jurusan Kedokteran Gigi, Fakultas Kedokteran, Universitas Jenderal Soedirman, Purwokerto, Indonesia

3 Program Profesi Kedokteran Gigi, Fakultas Kedokteran Universitas Jenderal Soedirman, Purwokerto, Indonesia.

\section{Abstrak}

Oral Candidiasis adalah infeksi yang disebabkan oleh jamur Candida albican. Infeksi candida dapat terjadi pada penderita Diabetes Mellitus (DM) karena kadar gula yang tinggi pada cairan rongga mulut dan penurunan imunitas penderita. Tujuan laporan kasus ini untuk membahas kasus dan penatalaksanaan acute erythematous candidiasis pada penderita diabetes mellitus. Pasien laki-laki usia 63 tahun datang Rumah Sakit Gigi dan Mulut dengan bagian dorsal terasa perih, panas dan sakit ketika makan dan minum. Rasa perih dirasakan sejak sekitar 2 bulan yang lalu setelah pasien mengalami jantung. Pasien mempunyai riwayat diabetes militus tekontrol, hipertensi terkontrol, asma dan gatritis. Pasien merasakan sakit pada lidahnya semakin parah disertai rasa panas dan nyeri ketika kondisi badan tidak sehat. Pasien didiagnosa kandidiasis akut eritematous dan diterapi dengan antijamur sistemik, obat kumur dan antiseptic topical untuk kasus rongga mulut dan dirujuk ke spesialis penyakit dalam untuk control gula darah. Pasien dinyatakan sembuh setelah 36 hari perawatan. Mengetahui faktor predisposisi pada kasus ini (DM) sangat penting dalam penatalaksanaan terapi Kandidiasis akut eritematous. Penderita diabetes mellitus harus rutin mengontrol kadar glukosa darah, menjaga kebersihan rongga mulut dan tidak memperparah dengan menambah faktor predisposisi lain.

Kata Kunci: Candida albican, diabetes melitus, oral candidiasis, terapi rongga mulu†

\section{Abstract}

Oral Candidiasis is infectious that caused by fungi Candida albican. Candida infection can happen on Diabetes mellitus patients (DM) because of glucose high level on oral cavity fluid and decreasing immunity patient. The purpose was to discuss and management acute erythematous candidiasis on DM patient. A 63-year-old male patient arrives at the Dental Hospital with dorsal pain, heat and pain when eating and drinking. Pain has been felt since about 2 months ago after the patient experienced heart disease. The patient has a history of controlled diabetes mellitus, controlled hypertension asthma and gastritis. The patient feels pain in his tongue getting worse accompanied by a burning sensation and pain when the body was unhealthy. The patient was diagnosed with acute erythematous candidiasis and treated with systemic antifungal, mouthwash and topical antiseptic for oral cavity cases and was referred to an internal medicine specialist for blood sugar control. The patient was declared cured after 36 days of treatment. Knowing the predisposing factors in this case (DM) is very important in the management of erythematous acute candidiasis therapy. Patients with diabetes mellitus must routinely control blood glucose levels, maintain oral hygiene and not worsen by adding other predisposing factors.

Keywords: Candida albican, diabetes mellitus, oral candidiasis, therapy in oral cavity

Korespondensi (Correspondence) : Aris Aji Kurniawan, Bagian Ilmu Penyakit Mulut, Jurusan Kedokteran Gigi, Fakultas Kedokteran. Jl. Dr. Soeparno, Kampus Karangwangkal Gedung E, Karang Bawang, Grendeng, Kec. Purwokerto Utara, Kabupaten Banyumas, Jawa Tengah 53122. Email: arisajikurniawan@gmail.com.

Oral Candidiasis adalah infeksi yang disebabkan oleh jamur Candida albicans yang sering terjadi pada rongga mulut. Candida albicans merupakan organisme komensal dalam rongga mulut yang bersifat apportunistic pathogens. Candida dapat menjadi pathogen apabila ada faktor predisposisi yang mengubah suasana dalam rongga mulut.l Faktor predisposisi dapat berasal dari lokal, contohnya merokok, penggunaan gigi tiruan, penggunaan topikal steroid dan kualitas saliva, sedangkan penderita dengan immunocompromised, chemotherapy, endocrine disorder merupakan contoh dari faktor sistemik. ${ }^{2}$

Manifestasi dari oral candidiasis dapat berbeda sesuai dengan faktor predisposisinya dan secara klinis terdapat empat bentuk yang berbeda: (a) acute pseudomembranous candidosis; (b) chronic erythematous candidosis; (c) acute erythematous candidosis; dan (d) chronic hyperplastic candidosis. ${ }^{2}$ Klasifikasi Oral candidiasis (OC) secara umum dibagi menjadi dua. Yang pertama adalah Primary OC dimana lesi hanya terdapat dioral dan perioral, terdiri dari acute: pseudomembranous erythematous chronic: erythematous dan hyperplastic; dan Candida- associated lesion (denture-induced stomatitis, angular cheilitis) dan median rhomboid glossitis. Yang kedua Secondary OC merupakan manifestasi oral dari systemic mucocutaneous candidal infection. ${ }^{3}$

Diantara beberapa jenis candidiasis, tipe erythematous merupakan candidiasis 
yang menimbulkan rasa sakit. Karakteristik dari Erythematous Candidiasis yaitu kemerahan lokal pada mukosa rongga mulut, umumnya pada lidah dan palatum.1,4 Dua bentuk dari erythematous candidiasis dapat dibedakan berdasarkan kondisi simptomatik dan asimptomatik. Simptomatik dihubungkan dengan adanya rasa terbakar/ burning sensation pada mulut atau lidah dan kemerahan. Sedangkan asimptomatik dihubungkan dengan kemerahan kronis lokal dan biasanya terjadi pada denture stomatitis. ${ }^{5}$ Infeksi candida dapat terjadi pada penderita Diabetes Mellitus (DM) karena kadar gula yang tinggi pada cairan rongga mulut dan penurunan imunitaspenderita. Penurunan sistem imun yang dimaksud yaitu terjadi gangguan opsonisasi dan penurunan aktivitas kemotaksis neutrofil dan monosit. Pada penderita diabetes tidak terkontrol terjadi penurunan flow saliva, $\mathrm{pH}$ dan peningkatan glukosa pada saliva dimana keadaan tersebut memfasilitasi pertumbuhan candida. ${ }^{6}$ Pada penderita diabetes mellitus tipe 2 ditemukan peningkatan jumlah Candida albicans dibandingkan terhadap bukan penderita diabetes.?

Individu imunokompeten jarang menderita oral candidiasis bahkan ketika Candida hadir dalam rongga mulut. Pencegahan infeksi mukosa oleh Candida dimediasi terutama oleh fungsi respon imun bawaan. Secara khusus, neutrofil dan makrofag berperan dalam mekanisme perlawanan terhadap candida. Fagosit menerima signal adanya Candida melalui pattern recognition receptors(PRRS), yang berinteraksi dengan molekul spesifik (pathogen-associated molecular patterns; PAMPs) yang terdapat pada permukaan Candida. Setelah terjadi pengenalan, sel-sel ini melepaskan sitokin dan kemokin untuk lebih memodulasi respon imun. Sel dendritik (DC) adalah antigen presenting sel profesional yang berperan pada jaringan mukosa. Interaksi DC dengan Candida menyebabkan aktivasi DC dan fagositosis. ${ }^{1}$
Setelah terjadi fagositosis, DC bermigrasi ke kelenjar getah bening di mana antigen Candida diproses dan disajikan pada permukaan DC untuk naif CD4 T-sel. Interaksi antara DC dan T-sel menyebabkan sel-T berdiferensiasi menjadi sel-T mature. Jenis T-sel yang dihasilkan antara lain T-helper 1 (Th1), Thelper 2 (Th2), T- helper 17 (Th17), dan Tregulator (Treg). Dimana diketahui sel T tersebut berperan terhadap pertahanan mukosa terhadap candida.lPrioritas dalam pengobatan oral candidiasis pada kasus ini adalah identifikasi faktor predisposisi dan mendapatkan riwayat kesehatan menyeluruh. Oleh karena itu, makalah ini membahas kasus dan penatalaksanaan acute erythematous candidiasis pada penderita diabetes mellitus.

\section{KASUS}

Pasien yang terlibat dalam kegiatan penelitian ini telah melakukan persetujuan dengan penandatangan informed consent. semua prosedur yang dilakukan dalam kegiatan ini merupakan prosedur standar digunakan di RSGMP Universitas Jenderal Soedirman Punwokerto.

Pasien laki-laki usia 63 tahun datang Rumah Sakit Gigi dan Mulut dengan bagian dorsal terasa perih, panas dan sakit ketika makan dan minum. Rasa perih dirasakan sejak sekitar 2 bulan yang lalu setelah pasien mengalami jantung. Pasien mempunyai riwayat diabetes militus tekontrol, hipertensi terkontrol, asama dan gatritis. Pasien menkonsumsi metformin untuk penyakit DMnya. kemudian pasien merasakan sakit pada lidahnya semakin parah disertai rasa panas dan nyeri ketika kondisi badan tidak sehat. Pasien memeriksakan sakitnya dan diberi obat Nystatin drop dan multifitamin. Selama 3 minggu pertama pemakaian nystatin lidah menjadi bersih tetapi masih ada rasa perih dan panas pada lidah, dan tidak lama kemudian lidah kembali kotor (gambar $1)$.

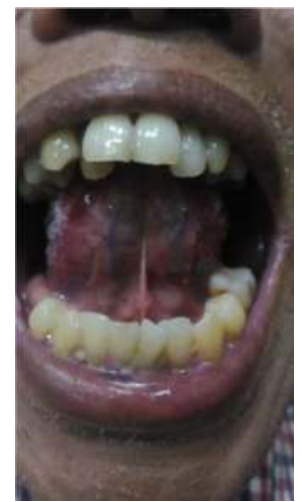

Gambar 1. Awal datang terdapat candida pada dorsal lidah dan inferior lidah 

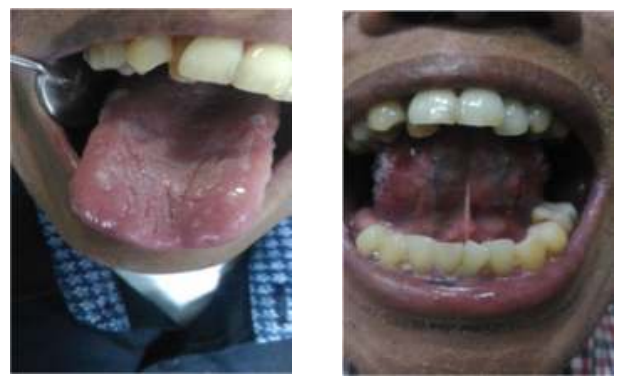

Gambar 2. Sesudah konsumsi nystatin terdapat candida pada dorsal lidah dan inferior lidah

\section{MANAJEMEN KASUS}

Pasien mempunyai riwayat diabetes melitus yang terkontrol dan hipertensi. Hal ini sangat menunjang sebagai faktor predisposisi munculnya oral candidiasis. Pada kunjungan pertama ini pengobatan ditujukan untuk meringankan keluhan simptomatisnya. Pemberian obat kumur Tantum Verde yg mengandung Benzidamin Hcl sebagai NSAID dimaksudkan untuk efek anestesi dan analgesiknya sehingga rasa sakit yang dikeluhkan pasien dapat berkurang. Pemberian Aloclair gel yang kandungannya antara lain: polyvinylpyrrolidone (PVP), aloe vera extract, sodium hyaluronate, glycyrhettinic acid. PVP memiliki efek sebagai antiseptik, PVP dan sodium hyaluronate dapat membentuk selaput lapisan sebagai barier pelindung mekanis, aloe vera extract sebagai antiinflamasi dan regenerasi jaringan, glycyrhettinic acid memiliki efek antivirus, antijamur, antiprotozoa serta antibakteri.

Teragrand- $M$ adalah multivitamin mengandung beberapa vitamin antara lain A, D, B1, B2, B6, B12 dan beberapa mineral : $\mathrm{Fe}$, lod, Mn, Zn, Mg. Berfungsi memenuhi kebutuhan vitamin dan mineral untuk meningkatkan daya tahan tubuh. Pada pasien juga dilakukan pemeriksaan penunjang berupa pemeriksaan patologi anatomi yaitu scrabbing pada lesi dilidah dan patologi klinik untuk pemeriksaan darah lengkap dan kadar glukosa darahnya karena dari riwayat pasien mempunyai penyakit sistemik.

Pada kunjungan kedua hasil patologi anatomi yaitu hasil scrabbing pada lesi dilidah didapatkan adanya infeksi candida berupa ditemukan spora dan hifa candida. Pada pemeriksaan patologi klinik didapatkan gambaran RBC, HCT, MCV, MCH, PLT yang berbeda dengan nilai rujukan normal tetapi tidak terlalu signifikan, Glukosa darah puasa: $134 \mathrm{mg} / \mathrm{dl}$, Glukosa darah 2 jam pp: 324 $\mathrm{mg} / \mathrm{dl}$. Menandakan bahwa saat ini pasien kadar glukosa darahnya masih tinggi dan merupakan faktor predisposisi yang baik untuk pertumbuhan oral candidiasis di lidahnya. Pasien juga disarankan rujuk ke Poli Penyakit Dalam untuk pengobatan diabetesnya. Karena sudah diketahui menurut hasil laboratorium bahwa ada infeksi candida maka pada kunjungan kali ini pasien diberi resep per oral obat flukonazole karena obat ini cukup efektif terhadap candida terutama dengan predisposisi faktor sistemik. Mekanisme obat golongan azole adalah dengan menginhibisi enzim lanosterol demethylase, suatu enzim P450, yang terlibat dalam sintesis ergosterol. Gangguan ergosterol dapat menghambat pertumbuhan candida dan menurunkan permeabilitas membran. 1 Pasien juga disarankan untuk rajin membersihkan lidahnya agar kotoran yang menempel pada lidah hilang dan membantu mempercepat penyembuhan lesi dilidahnya.

Pemberian fluconazole dapat meningkatkan sekresi saliva, seperti diketahui bahwa pada penderita diabetes sekresi saliva berkurang sehingga pemberian flukonazole dianjurkan.' Seperti telah diketahui bahwa pada penderita diabetes sekresi saliva akan berkurang, hal ini menyebabkan berkurangnya aktivitas enzim anticandida yang terkandung dalam saliva menyebabkan hifa Candida albicans makin melekat kuat pada lapisan superfisial epitel. Pasien juga diberi obat kumur aloclair untuk menjaga oral hygiene dan membantu proses penyembuhan. Pasien dingatkan untuk menjaga oral hygiene dan selalu kontrol rutin ke bagian penyakit dalam untuk memantau kadar glukosa darahnya, karena dengan kadar glukosa darah yang semakin membaik akan menunjang dalam kesembuhan lesi dilidahnya.

Pada kunjungan keempat pasien datang sudah tidak mengeluhkan sakitnya, dan secara klinis keadaan lesi di lidahnya sudah baik dan ada kesembuhan. Pasien juga membawa hasil cek glukosa darah terbaru yaitu Glukosa darah puasa $102 \mathrm{mg} / \mathrm{dl}$ dan glukosa darah 2 jam pp $232 \mathrm{mg} / \mathrm{dl}$. Obat minum flukonazole sudah habis. diminum dan obat kumur aloclair juga sudah habis digunakan sesuai anjuran. Pasien telah dinyatakan sembuh. Disarankan tetap kontrol rutin ke penyakit dalam untuk mengontrol glukosa darahnya agar tetap baik serta selalu menjaga kebersihan rongga mulutnya.

\section{PEMBAHASAN}

Oral Candidiasis (OC) merupakan infeksi oportunistik yang paling sering mempengaruhi 
mukosa mulut dan disebabkan oleh ragi Candida albicans. Proses pathogenesis tidak sepenuhnya dipahami, tetapi sejumlah faktor predisposisi memiliki kemampuan untuk membuat sifat Candida dari flora komensal normal (saprofit) menjadi patogen(parasit). C. albicans biasanya merupakan patogen yang lemah, tetapi candidiasis lebih mudah mempengaruhi individu yang sangat muda, usia lanjut/ tua, dan dalam kondisi yang sakit. ${ }^{?}$ Penyebab candidiasis oral umumnya adalah jamur Candida albicans. Dalam rongga mulut, Candida albicans dapat melekat pada mukosa labial, mukosa bukal, dorsum lidah, dan daerah palatum. Candida menjadi patogenik pada pasien dengan faktor predisposisi sehingga mempermudah terjadinya infeksi oportunistik Kondisi yang mempermudah terjadinya candidiasis oral adalah: usia tua, higiene oral yang buruk, merokok dan gangguan endokrin (diabetes melitus). ${ }^{1}$

Pada stadium inaktif, bentuk yeast mendominasi, tetapi saat terjadi aktivitas patologis lebih banyak ditemukan bentuk hypae. Untuk menginvasi lapisan mukosa, candida harus melekat pada permukaan epitel. Penetrasi yeast ke sel epitel difasilitasi oleh produksi lipase.2 Untuk melekat dan penetrasi pada epitel mukosa, Candida albicans akan mensekresikan enzim hidrolitik. Enzim hidrolitik yang dihasilkan Candida albicans ada 3 macam, yaitu Secreted Aspartyl Proteinase (SAP), fosfolipase B, dan lipase. Penetrasi Candida albicans berlangsung dengan cara hifa akan masuk ke dalam lapisan epitel melalui rongga interselular secara thigmotropism, seperti pada tanaman fungi dan pada Candida albicans yang dilihat secara in vitro yaitu hifa akan bergerak berdasarkan adanya sentuhan hifa dengan sel epitel. Berkurangnya aktivitas enzim anticandida yang terkandung dalam saliva menyebabkan hifa Candida albicans yang telah melekat kuat pada lapisan superfisial epitel dapat melakukan penetrasi dengan mudah melalui lapisan epitel. Adanya lesi pada lapisan superfisial epitel menyebabkan rasa seperti terbakar, rasa tidak enak, dan sakit sehingga pasien kesulitan untuk makan dan minum. 10

Pasien mempunyai riwayat diabetes melitus yang terkontrol dan hipertensi. Hal ini sangat menunjang sebagai faktor predisposisi munculnya oral candidiasis. Pada kunjungan pertama ini pengobatan ditujukan untuk meringankan keluhan simptomatisnya. Pemberian obat kumur Tantum Verde yg mengandung Benzidamin Hcl sebagai NSAID dimaksudkan untuk efek anestesi dan analgesiknya sehingga rasa sakit yang dikeluhkan pasien dapat berkurang. Pemberian Aloclair gel yang kandungannya antara lain : polyvinylpyrrolidone (PVP), aloe vera extract, sodium hyaluronate, glycyrhettinic acid. PVP memiliki efek sebagai antiseptik, PVP dan sodium hyaluronate dapat membentuk selaput lapisan sebagai barier pelindung mekanis, aloe vera extract sebagai antiinflamasi dan regenerasi jaringan, glycyrhettinic acid memiliki efek antivirus, antijamur, antiprotozoa serta antibakteri."

Acute erythematous candidiasis pada penderita DM dapat didiagnosa secara pasti dilihat berdasarkan anamnesis, pemeriksaan klinis yaitu lesi kemerahan pada lidah dengan keluhan perih dan panas, pemeriksaan penunjang yaitu berupa pemeriksaan darah lengkap dan pemeriksaan kadar glukosa darah, serta swab candida dimana ditemukan positif candida. Pada pengobatan sebelumnya penderita juga telah diberikan nistatin tetes, namun kurang adekuat disebabkan oleh karena faktor predisposisi belum ditemukan serta pemberian antibiotik untuk terapi. Mengetahui faktor predisposisi pada kasus ini (DM) sangat penting dalam penatalaksanaan terapi Acute erythematouscandidiasis. Penatalaksanaan dari kasus ini yaitu dengan mengeliminasi faktor predisposisi dalam hal ini kadar glukosa darahnya harus baik, kebersihan rongga mulut tercapai dan pemberian obat-obatan anticandida.

Pasien yang menderita diabetes melitus harus benar-benar rutin kontrol untuk menjaga kadar glukosa darahnya baik, serta wajib menjaga kebersihan rongga mulut. Tidak memperparah dengan faktor predisposisi lain, misal : tidak merokok, tidak menggunakan antibiotik jangka panjang dan berlebihan tanpa pengawasan dokter.

\section{DAFTAR PUSTAKA}

1. Williams D., Lewis M. Pathogenesis and treatment of oral candidosis. Journal of Oral Microbiology, 2011; 3: 5771.

2. Greenberg MS, Glick M, Ship JA. Burket's oral medicine 1 led. Hamilton, BC Decker Inc. 2008. p. 92-77.

3. Nurdiana JM. Pseudomembranous candidiasis in patient wearing full denture Dental. Journal Majalah Kedokteran Gigi, 2009; 42(2): 60-4.

4. Gracia MPT, Fernández $\mathrm{CMH}$, Cebrian BM, García BS. Chronic Hyperplastic Candidiasis of the Oral Mucosa: Case Report. J Clin Stud Med Case Rep, 2014; 1:001.

5. McCullough MJ, Savage NW. Oral candidosis and the therapeutic use ofantifungal agents in dentistry. Australian Dental Journal Medications Supplement, 2005; 50: 4.

6. Tarçın BG. Oral Candidosis: Aetiology, Clinical Manifestations, Diagnosis and Management. Journal of Marmara University Institute of Health Sciences,2011; 1(2). 
7. Jafari A., Khanpayah E., Ahadian H. Comparison the Oral Candida Carriage in Type 2 Diabetic and Non Diabetics. Jundishapur Journal of Microbiology, 2013; 6(7).

8. Susilo J, Setiawati A, Darmansjah I, Indarti J, Kusuma F. Low-dose ketoconazole-fl uconazole combination versus fl uconazole in single doses for the treatment of vaginal candidiasis.
Medical journal Indonesia, 201 1; 20(3).

9. Ellepola AN, Samaranayake LP. Inhalational and topical steroids, and oral candidosis: a mini review. Oral Dis, 2001; 7: 216-211.

10. Anaissie EJ, MCGinnis MR, Pfealler MA. Clinical Mycology. Ed 2. London Elsevier. 2009. P. 200-1 